\title{
Sewage discharges and nutrient levels in Marimba River, Zimbabwe
}

\author{
I Nhapi ${ }^{1 *}$ and S Tirivarombo ${ }^{2}$ \\ ${ }^{1}$ Department of Civil Engineering, University of Zimbabwe, Box MP167, Mt Pleasant, Harare, Zimbabwe, \\ ${ }^{2}$ Department of Environmental Science and Technology, Chinhoyi University of Technology, Private Bag 7724, Chinhoyi, Zimbabwe
}

\begin{abstract}
Population distribution, land-use, industrial activity, urban agricultural activities, and pollution control strategies in Harare, Zimbabwe, have all changed significantly since independence in 1980. The effects of these changes on water quality and the consequences on human and ecological health are of major economic and social importance. This study looked at pollution in the Marimba River, one of the major inflow rivers into the Lake Chivero, Harare city's main water supply source. The river was characterised using standard physical and chemical methods to assess water quality from June 2000 to December 2001. Monthly sampling results indicated high pollution levels, especially nutrients. Nitrogen values averaged $13.5 \pm 2.0 \mathrm{mg} \cdot \ell^{-1}$ as $\mathrm{N}$, and phosphorus $2.6 \pm 0.6 \mathrm{mg} \cdot \ell^{-1}$ as $\mathrm{P}$ at the river’s discharge point into Lake Chivero. The high nutrient values, exceeding acceptable limits, are indicative of industrial, agricultural, and sewage discharges upstream. The gross river pollution levels are detrimental to the downstream Lake Chivero. It was concluded that although there are other significant incidental sources of nutrient pollution in Marimba River, sewage effluent is by far the major polluter. It was established that pond overflow from Crowborough Sewage Treatment Works is the major source of sewage inflows and treating this to tertiary standard would result in $46 \%$ and $35 \%$ reductions respectively for total nitrogen and total phosphorus loads in the Marimba River
\end{abstract}

Keywords: mass balance, nutrients, pollution, pasture irrigation, sewage treatment, water quality

\section{Introduction}

Nutrient enrichment is a major threat to freshwater ecology, leading to severe pollution problems. The disposal of untreated or partially treated wastewater into rivers is quite common in developing countries. This involves the discharge of nitrogen and phosphorus; the major nutrients that control biomass growth (Welch and Lindell, 1980) and these are available in abundance in municipal wastewater. In Zimbabwe, eutrophication-related problems have been reported in Lake Chivero (Moyo, 1997). The lake is located $35 \mathrm{~km}$ downstream of the capital city of Harare and supplies approximately 70\% of the potable water needs in the area. Studies by JICA (1996) and Moyo and Worster (1997) suggest that the eutrophication of Lake Chivero is due to inappropriate sewage discharges. Earlier reports by Thornton and Nduku (1981) and McKendrick (1982) also point to a relationship between sewage discharges and water quality deterioration. Soluble nutrient concentrations have often been higher than permissible levels for drinking water in lakes of $0.3 \mathrm{mg} \cdot \ell^{-1}$ Total Nitrogen (TN) and $0.01 \mathrm{mg} \cdot \ell^{-1}$ Total Phosphorus (TP) (JICA, 1996).

The Mukuvisi and Marimba Rivers drain the City of Harare and discharge into Lake Chivero. A lot of interest has been generated on pollution in the Marimba River subcatchment. The impact of effluent discharges from the Workington Industrial Area and those of treated and partially treated sewage from Crowborough Sewage Treatment Works (CSTW) on the quality of the Marimba River was studied by Mathuthu et al. (1997). The levels of virtually all the water quality parameters monitored went up downstream of the sewage discharge point. Levels of phosphates exceeded maximum allowable WHO limits of $0.5 \mathrm{mg} \cdot \ell^{-1}$ and nitrates remained within

\footnotetext{
* To whom all correspondence should be addressed.

푱 +263 23414 529; fax: +263 4 303288; e-mail: inhapi@eng.uz.ac.zw Received 29 October 2002; accepted in revised form 1 October 2003.
}

acceptable limits for effluent water. In a related study, Manjonjo (1999) also found that sewage effluent and irrigation seepage and runoff were impacting significantly on nutrient and heavy metal levels in the Marimba River.

The deterioration of water quality in the major inflow rivers into Lake Chivero greatly affects water treatment, rendering it more sophisticated and expensive. The major uses of water in the Lake are potable water supply, agriculture, recreation and supporting aquatic life. This paper focuses on a study that was carried out from June 2000 to December 2001 on the influence of sewage discharges on nitrogen and phosphorus loads in the Marimba River. The current paper reports on a part of a broader study on the Marimba River subcatchment focusing on sewage treatment efficiency, effluent polishing via pasture irrigation, and nutrient levels in the Marimba River. This study investigated the contribution of sewage from CSTW and its pastures to the nitrogen and phosphorus levels in the Marimba River. On a broader scope, the study contributed to water resource quality monitoring and assessment, and the development of local information systems to support decision-making.

\section{Materials and methods}

\section{The study area}

The study area is the Marimba River subcatchment, an area covering $189 \mathrm{~km}^{2}$ (Fig. 1). The studied area starts from just upstream of sewage discharge points up to the entrance into Lake Chivero. Marimba River stretches for about $25 \mathrm{~km}$ originating in the University of Zimbabwe grounds. It flows through the northern and western parts of Harare's commercial centre, collecting surface runoff from low-, medium- and high-density areas. It also flows through the Workington Industrial Area. After collecting sewage effluent from CSTW, the river passes through commercial farming 


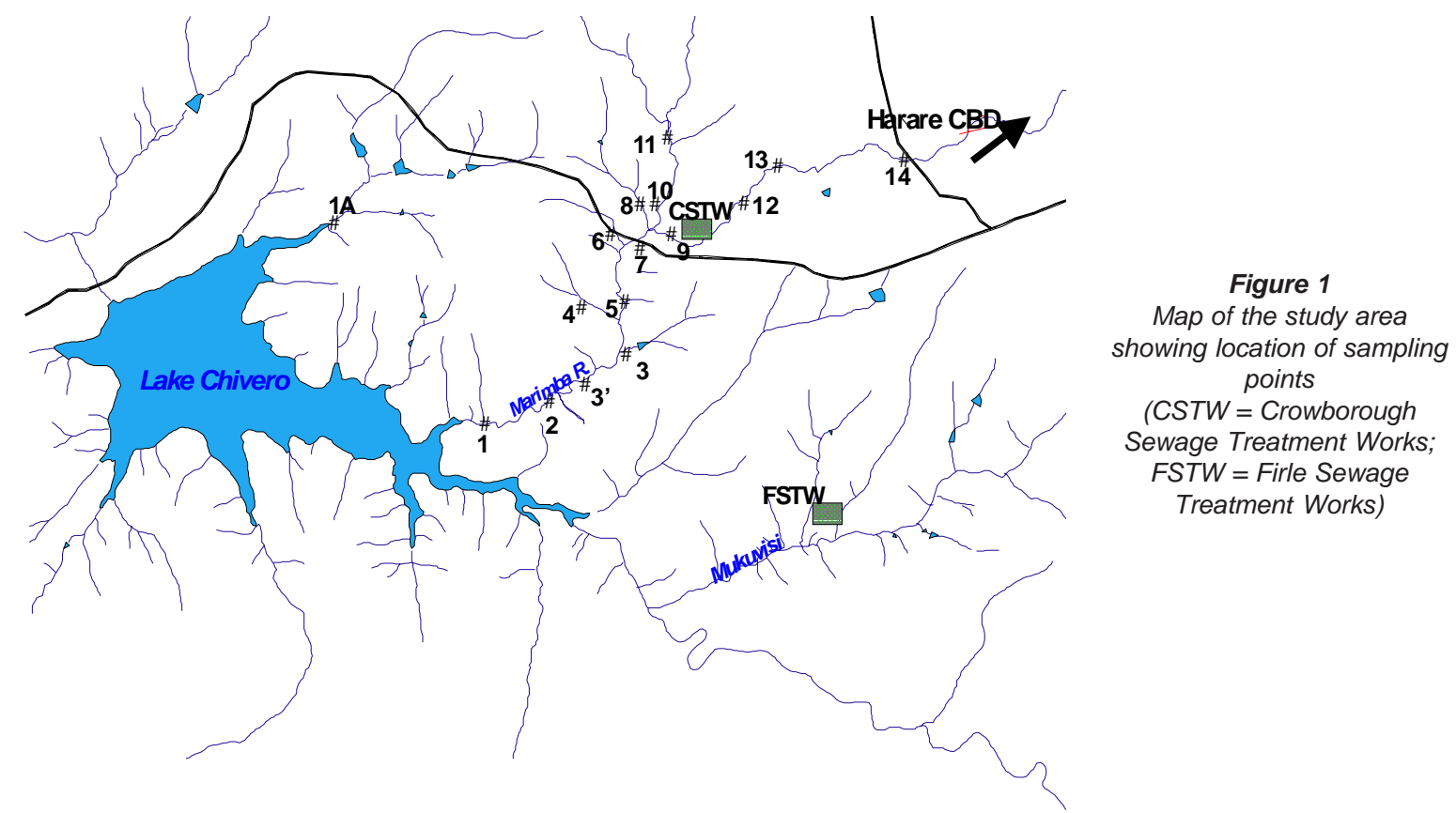

areas before discharging into Lake Chivero. The CSTW has a design capacity of $54000 \mathrm{~m}^{3} \cdot \mathrm{d}^{-1}$ but was treating about 103000 $\mathrm{m}^{3} \cdot \mathrm{d}^{-1}$ in December 2001. The plant comprises a biological nutrient removal (BNR) system with a capacity of $18000 \mathrm{~m}^{3} \cdot \mathrm{d}^{-1}$ which discharges into the Marimba River and a trickling filter (TF) system with a capacity of $36000 \mathrm{~m}^{3} \cdot \mathrm{d}^{-1}$ which discharges final effluent mixed with primary and secondary sludge to the pastures.

\section{Sampling and analysis}

The sampling locations chosen reflect different activities in the river reach (upstream, midstream and downstream) which may affect the quality situation in the river. A total of 14 river sampling points were established on the Marimba and Little Marimba Rivers. Station 1 is just before the river enters into Lake Chivero. Station 2 is about $3 \mathrm{~km}$ upstream where there is a flow-gauging station (C24). Other points were located on tributaries of the Marimba River with Station 3 draining Ingwe Pasture Irrigation Farm. Stations 10 and 11 are on the Little Marimba and monitor runoff and seepage from Crowborough Pasture Irrigation Farm. Similar stations $(9,12$, and 13) were established on the main Marimba River to cater for the influence of sewage discharges and seepage/ runoff from the other side of Crowborough Pastures. Stations 11 and 13 are upstream of sewage influence and acted as reference points. In addition, the influent and effluent streams from CSTW were monitored. In a related study, seepage, runoff, and irrigation points on the Little Marimba River were sampled to estimate the impact of pasture irrigation on the river system.

Samples were taken monthly from June 2000 to December 2001 to capture seasonal variations in water quality. The study focused on TN, TP, chemical oxygen demand (COD) and flows. The TN was taken as the sum of total Kjeldahl nitrogen (TKN) and nitrate-nitrogen $\left(\mathrm{NO}_{3}-\mathrm{N}\right)$. Nitrite-nitrogen $\left(\mathrm{NO}_{2}-\mathrm{N}\right)$ levels were observed to be too low $\left(<0.02 \mathrm{mg} \cdot \ell^{-1}\right)$ after the first five sampling runs and therefore left out of the analysis. Monthly river samples were collected, stored and analysed according to standard procedures (Standard Methods, 1995). Samples were also collected from CSTW on a monthly basis. Samples were collected in plastic containers that had been washed with phosphorus-free detergents, rinsed with distilled water and left to stand overnight in $1 \mathrm{M} \mathrm{HCl}$
They were rinsed again with distilled water and twice with sample water on site. In the field, samples were stored in cooler boxes with ice blocks, and later preserved and stored at about $4^{\circ} \mathrm{C}$ in the laboratory before analysis.

The TP was determined by digesting samples with concentrated sulphuric and nitric acids followed by the analysis of phosphate content using the vanado molybdophosphoric acid method. Nitrate was determined using the electrode screening method (WTW Microprocessor pH/ion meter pMX 300). Samples for TKN analysis were digested according to the micro-Kjeldahl method followed by distillation with sodium hydroxide and sodium thiosulphate solution. The released ammonia was collected in excess boric acid and determined by titration with $0.02 \mathrm{M}$ sulphuric acid. The obtained data were analysed statistically using Microsoft Excel. Extensive use was also made of the JICA Report of 1996, which dealt with major pollution issues in the Lake Chivero catchment.

\section{River flow measurement}

Flows were obtained from continuous gauging stations data from the Zimbabwe National Water Authority (ZINWA) and the City of Harare. Other flows were measured using the current meter method at Stations 3, 11, and 12. A Weathertronics suspension-type water current meter, model 6640, was used with the following formula provided by the manufacturer for calculating flows:

$$
\mathrm{Q}=\mathrm{A}(\mathrm{KR} / \mathrm{T}-\mathrm{C})
$$

where:

$\mathrm{Q}=$ flow, $\mathrm{m}^{3} \cdot \mathrm{s}^{-1}$

$\mathrm{A}=$ cross-sectional area of the channel under flow, $\mathrm{m}^{2}$

$\mathrm{K}=$ cup characteristic constant, 0.7

$\mathrm{R}=$ number of cup revolutions over the time interval $\mathrm{T}$

$\mathrm{C}=$ slip constant, 0.02, supplied with the instrument.

Water depths were determined at $200 \mathrm{~mm}$ intervals along the river cross-section and velocities measured at $2 / 3$ depth of each segment (Lewis et al., 1984). Flows at Station 2 were obtained from continuous flow readings from ZINWA. Distances between sampling points were measured using a planimeter. 
Figure 2

Schematic diagram of the river reach

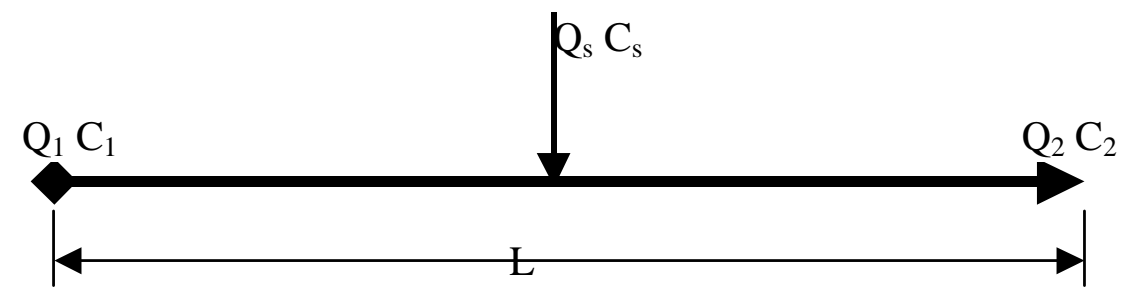

\section{Determination of pollution load reduction}

The stream-water quality trends caused by changes in sewage effluent quality were predicted using the 'screening model' (Hlavinek and Riha, 2001). The model is based on current and historical water quality data obtained from water quality measurement and analysis. The change in pollution sources produces the change in stream-water quality along the corresponding streams downstream from the pollution orifice while the stream selfpurification effect depends only on the stream water pollution concentration changed. This approach enabled prediction of the stream-water quality improvement without the detailed knowledge about all pollution sources in the catchment, which is quite an expensive and time-consuming process. The precise estimate of the efficiency of the anticipated pollution sources improvement is still necessary. An assessment of the rates of nutrient load reductions with distance was done based on the schematisation of the river reach as shown in Fig. 2 and Eq. (2).

$$
\mathrm{S}_{\mathrm{r}}=\frac{\mathrm{Q}_{1} \mathrm{C}_{1}+\mathrm{Q}_{\mathrm{s}} \mathrm{C}_{\mathrm{s}}-\mathrm{Q}_{2} \mathrm{C}_{2}}{\mathrm{~L}} \quad \mathrm{~g} \cdot \mathrm{s}^{-1} \cdot \mathrm{m}^{-1}
$$

where:

$\mathrm{Q}_{1} \mathrm{C}_{1}=$ pollution load at the upstream station, $\mathrm{g} \cdot \mathrm{s}^{-1}$

$\mathrm{Q}_{2} \mathrm{C}_{2}=$ pollution load at the downstream station, $\mathrm{g} \cdot \mathrm{s}^{-1}$

$\mathrm{Q}_{\mathrm{s}} \mathrm{C}_{\mathrm{s}}=$ point source pollution load in the river reach, $\mathrm{g} \cdot \mathrm{s}^{-1}$

$\mathrm{L}^{\mathrm{s}}=$ distance between the two points 1 and $2, \mathrm{~m}$.

\section{Results and discussion}

\section{Field measurements}

Results for field measurements are shown in Table 1 . The recorded river temperatures ranged between $21^{\circ} \mathrm{C}$ to $25^{\circ} \mathrm{C}$ for the wet season and $18^{\circ} \mathrm{C}$ to $24^{\circ} \mathrm{C}$ for the dry season. Temperatures were below the standards limit of $35^{\circ} \mathrm{C}$ (Government of Zimbabwe, S. I. 274 of 2000). Most stations had a $\mathrm{pH}$ of 6.5 to 7.8 except for those downstream of Station 3, which receives seepage and runoff from Ingwe Farm. Occasionally high pH levels observed were attributed to high levels of photosynthetic activity. Photosynthesis elevates $\mathrm{pH}$ in proportion to the rate of removal of free $\mathrm{CO}_{2}$; the higher the removal rate, the higher the $\mathrm{pH}$ or the less the acidity (Billings, 1984). Stations upstream of sewage discharge generally had higher dissolved oxygen (DO) levels, consistent with less polluted waters. Downstream, oxygen levels were gradually increasing due to the exhaustion of readily biodegradable organic matter, rapids and turbulent flow patterns. Electrical conductivity levels were mostly higher than $500 \mathrm{mS} \cdot \mathrm{cm}^{-1}$, which is much higher than expected levels in rivers. Higher turbidity levels were observed after sewage discharge mainly due to residential and urban agricultural runoff, pond overflow, and pasture runoff. High turbidity, apart from seriously detracting from aesthetic characteristics of water, may render the water unsuitable for domestic, industrial, and agricultural uses. Excessive turbidity in water can cause water purification problems, reducing filter run times. When highly turbid waters are

\begin{tabular}{|c|c|c|c|c|c|}
\hline \multicolumn{6}{|c|}{$\begin{array}{l}\text { TABLE } 1 \\
\text { Mean field values for various parameters along the } \\
\text { Marimba River Oct } 2000 \text { to Nov } 2001 \text { ( } n=7 ; \\
\pm \text { standard deviation) }\end{array}$} \\
\hline Station & $\begin{array}{l}\text { Tempera- } \\
\text { ture }\left({ }^{\circ} \mathrm{C}\right)\end{array}$ & $\mathrm{pH}$ & $\begin{array}{c}\mathrm{DO} \\
\left(\mathrm{mg} \cdot \ell^{-1}\right)\end{array}$ & $\begin{array}{c}\text { Turbidity } \\
\text { (NTU) }\end{array}$ & $\begin{array}{c}\text { Conducti- } \\
\text { vity }\left(\mu \mathrm{S} \cdot \mathrm{cm}^{-1}\right)\end{array}$ \\
\hline 1 & $21 \pm 3$ & $6.9 \pm 1.2$ & $3.3 \pm 2.0$ & $16 \pm 22$ & $578 \pm 53$ \\
\hline 2 & $20 \pm 2$ & $7.6 \pm 1.8$ & $2.9 \pm 2.1$ & $16 \pm 23$ & $534 \pm 34$ \\
\hline 3 & $23 \pm 2$ & $6.8 \pm 0.7$ & $4.7 \pm 0.7$ & $15 \pm 12$ & $685 \pm 141$ \\
\hline 3' & $22 \pm 2$ & $7.1 \pm 1.0$ & $2.5 \pm 1.6$ & $11 \pm 13$ & $658 \pm 51$ \\
\hline 5 & $22 \pm 2$ & $6.6 \pm 1.1$ & $2.6 \pm 2.7$ & $9 \pm 7$ & $557 \pm 85$ \\
\hline 7 & $22 \pm 1$ & $6.2 \pm 0.8$ & $3.1 \pm 3.8$ & $36 \pm 34$ & $509 \pm 119$ \\
\hline 9 & $21 \pm 3$ & $7.4 \pm 0.5$ & $3.0 \pm 1.5$ & $56 \pm 35$ & $607 \pm 39$ \\
\hline $9 \mathrm{U}$ & $18 \pm 3$ & $7.9 \pm 0.5$ & $5.1 \pm 3.0$ & $20 \pm 10$ & $534 \pm 29$ \\
\hline 10 & $19 \pm 3$ & $7.3 \pm 0.4$ & $5.0 \pm 2.1$ & $12 \pm 14$ & $592 \pm 26$ \\
\hline 11 & $25 \pm 4$ & $6.5 \pm 0.6$ & $6.4 \pm 1.8$ & $8 \pm 7$ & $457 \pm 76$ \\
\hline 12 & $22 \pm 2$ & $7.2 \pm 0.3$ & $2.2 \pm 1.2$ & $12 \pm 12$ & $440 \pm 87$ \\
\hline 13 & $23 \pm 1$ & $6.9 \pm 0.7$ & $2.6 \pm 1.6$ & $9 \pm 9$ & $370 \pm 97$ \\
\hline
\end{tabular}

chlorinated there may also be a tendency to increase trihalomethane (THM) precursors. Elevated turbidities are often associated with the possibility of microbiological contamination, as high turbidity makes it difficult to disinfect water properly.

\section{Laboratory analysis}

Figure 3 shows the TN and TP levels at various points along the Marimba and Little Marimba Rivers. Stations 12 and 13 are upstream of CSTW. There was a gradual increase in TP levels from these points to Station 9U, which is just before the pond effluent discharges into the Marimba River. The increase is attributed to irrigation runoff and seepage from Crowborough pastures. The effects of Crowborough pastures were also evident along the Little Marimba River. There was a gradual increase in TP levels from Station 11 up to 10, marking upstream and downstream points respectively on the Little Marimba River. The applicable WHO guideline for $\mathrm{P}$ in water systems that will reduce the likelihood of algal and other plant growth is $5 \mu \mathrm{g} \cdot \ell^{-1}$ (WHO, 1984) and this was exceeded at all points monitored. Station $1 \mathrm{~A}$ had lower pollutant concentrations than the Marimba River and it shows pollution effects of non-urbanised areas.

The WHO safe limit of $10 \mathrm{mg} \cdot \ell^{-1} \mathrm{NO}_{3}-\mathrm{N}$ in domestic water for lifetime use (WHO, 1984) was often exceeded at some sites, making the river water unsuitable for direct domestic use, as this would expose infants and pregnant women to the risk of methaemoglobinemia. There are squatters who abstract water form the Marimba River and its banks, closer to Station 2. Oxidation of the $\mathrm{NH}_{4}-\mathrm{N}$ was evident downstream where $\mathrm{DO}$ and $\mathrm{NO}_{3}-\mathrm{N}$ levels were high. This is related to the turbulent nature of flow in the shallow river with average depth $<1 \mathrm{~m}$. Nitrates from fertiliser and 


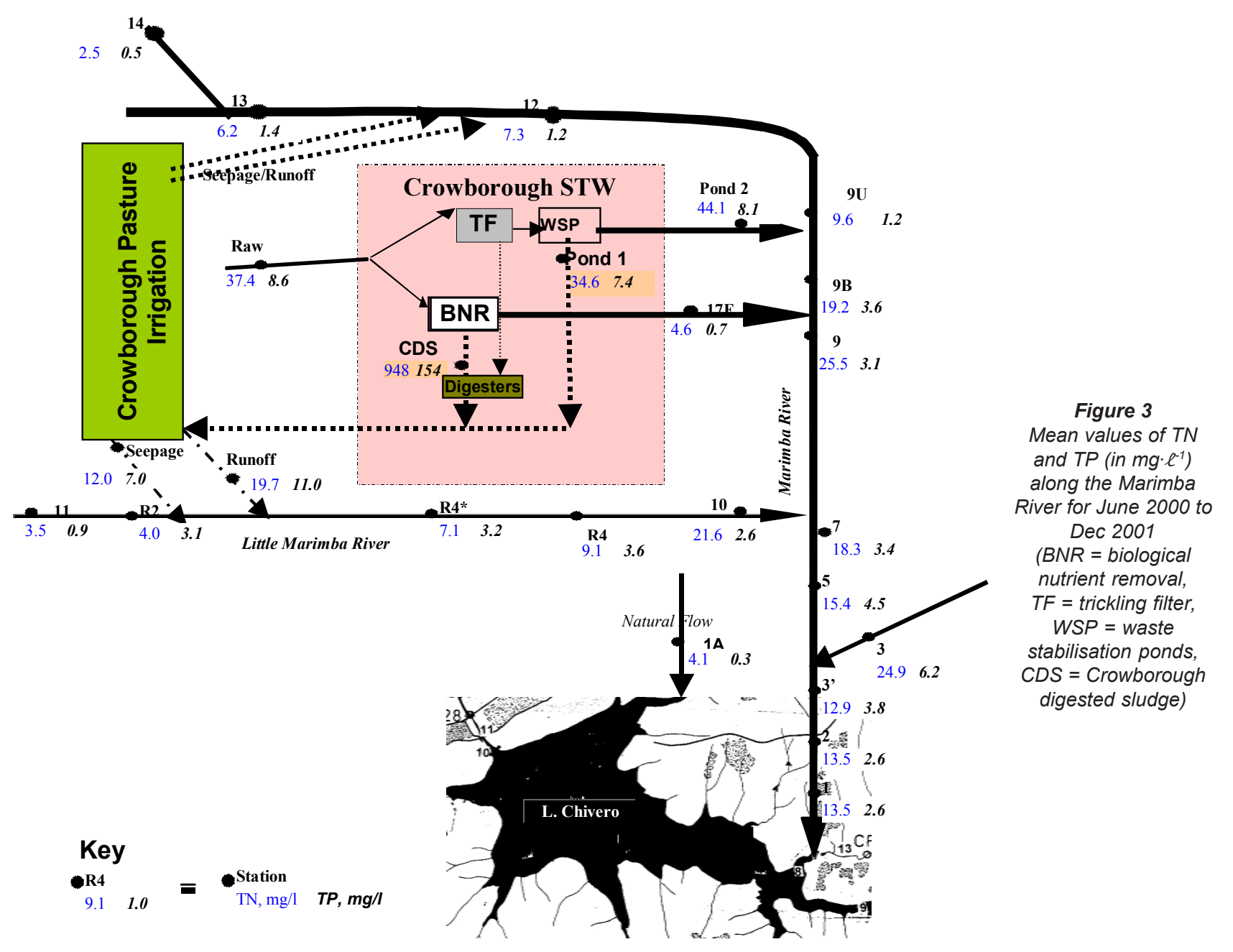

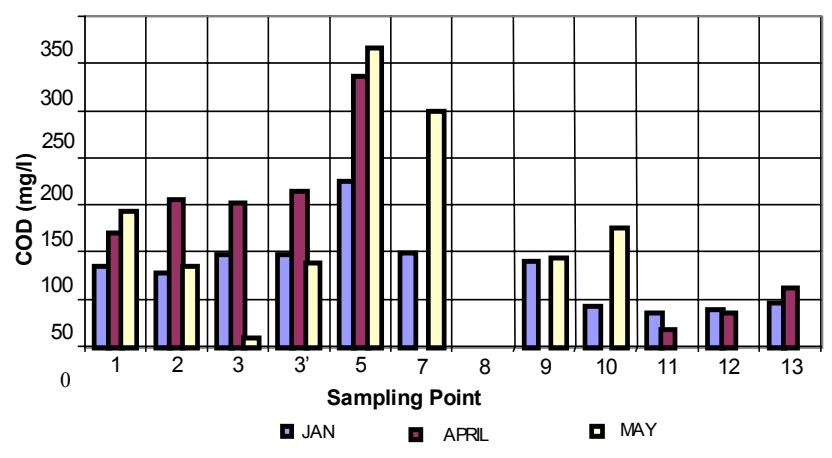

Figure 4

COD levels along the Marimba and Little Marimba Rivers for monitored months in year 2001

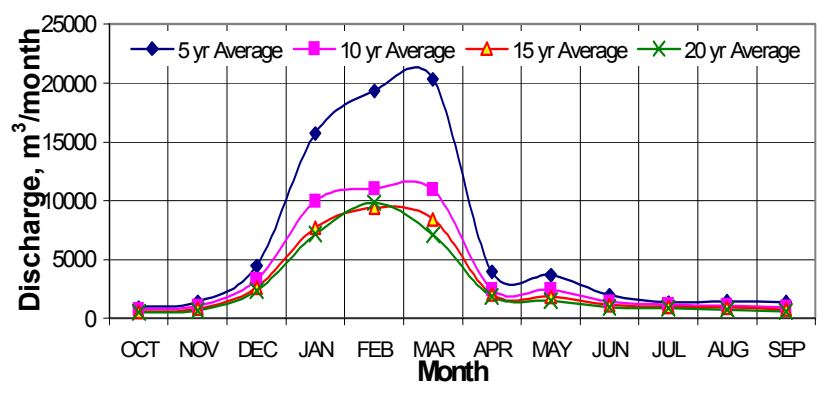

Figure 5

Average flow pattern at gauging station C24 (Sampling Point 2) on the Marimba River, 1980 to 2001 (Data source: ZINWA) leachates could also have contributed to increased nitrate levels further downstream. In some cases, downstream values were higher than upstream values whilst there was no further source of pollution within that stretch. This occurred in the dry season and it was attributed to water losses via evapotranspiration and aerosol effects related to rapids.

Eutrophication-related problems in warm water aquatic systems begin to increase at ambient TP concentrations exceeding 0.3 to $0.7 \mathrm{mg} \mathrm{P} \cdot \ell^{-1}$ (Fatoki et al., 2001). The associated TN concentrations would also be of the order 0.3 to $0.7 \mathrm{mg} \mathrm{N} \cdot \ell^{-1}$. These threshold values were exceeded in the Marimba River and the receiving Lake Chivero (Nhapi et al., 2001) where eutrophication is well pronounced. The abnormally high levels of TN and TP downstream of sewage discharge confirmed that sewage treatment plant effluent is the major source of pollution in the river. The river failed to recover sufficiently before discharging into Lake Chivero. The nutrient levels found in this study are much higher than those found by Machena (1997), Zaranyika (1997), and Kamudyariwa (2000) for the Mukuvisi River; and Mathuthu et al. (1997) and Manjonjo (1999) for the Marimba River. Stations upstream of CSTW had COD averages of 20 to $40 \mathrm{mg} \cdot \ell^{-1}$. This was attributed to industrial discharges and urban runoff. Downstream, the COD levels decreased with distance due to self-purification, in a manner consistent with DO levels increase in the stream (Fig 4).

\section{Flow and nutrient loads}

Figure 5 shows the flow pattern of gauging Station C24, which was also used as Sampling Point 2 in this study. This figure shows that 
recent years have received very good rains compared to long-term averages. The mean daily flow based on a 10year average was found to be $127682 \mathrm{~m}^{3} \cdot \mathrm{d}^{-1}$ and this was adopted for subsequent calculations. Flows upstream were estimated using the current metering method. Other flows were obtained by applying the mass balance analysis approach assuming negligible water losses. Seepage and runoff flows were obtained from Mawere (2001) as $17140 \mathrm{~m}^{3} \cdot \mathrm{d}^{-1}$ and $1635 \mathrm{~m}^{3} \cdot \mathrm{d}^{-1}$ respectively. The BNR effluent from CSTW was assumed to be the design capacity of $18000 \mathrm{~m}^{3} \cdot \mathrm{d}^{-1}$ as no overloading is allowed in this part of the treatment plant. Effluents pumped to pasture irrigation at Ingwe and Crowborough Farm were obtained from pumping records assuming that performance has not varied much from design pumping flow. Pond overflow was then estimated from a mass balance. Results of an assessment of the impact of sewage water on hydraulic flows in the Marimba River (Fig 6) showed a weak correlation between sewage discharges into the Marimba River and gauged flows at C24 (correlation coefficient 0.49). This suggests some influence from other contributors to river flow like sewer overflows, industrial discharges, seepage and runoff, which parameters are variable in time. The results also showed that at least $50 \%$ of the river flow is sewage effluent. The obtained water and nutrient loads along the Marimba River are shown in Table 2.

An attempt was made to develop nutrient and water balances for the studied portion of Marimba River. Problems were encountered in defining parameters related to water losses. The river was estimated to have an average width of $6 \mathrm{~m}$ and depth of $1 \mathrm{~m}$. An average evaporation loss of $5.3 \mathrm{~mm} \cdot \mathrm{d}^{-1}$ was derived from Department of Water Development (1995) and increased by a factor of 1.2 to cater for turbulence and rapids effects. The calculated evaporation losses for the entire river portion studied then amounted to $0.42 \%$ of the daily flows, and this was considered negligible. The contribution of direct rainfall on the river, using $812 \mathrm{~mm} \cdot \mathrm{yr}^{-1}$ annual rainfall (ZINWA figures), was also very low at $0.07 \%$ of annual river flow. The resultant mass balance is shown in Table 3.

The TN difference of $555 \mathrm{~kg} \cdot \mathrm{d}^{-1}(24 \%)$ was attributed to nitrogen losses through ammonia volatilisation, denitrification or sedimentation. The low $\mathrm{pH}$ levels and high DO concentrations at some of the points supports this assumption. Sediments have a high adsorption capacity for phosphorus and would account for the $37 \%$ loss in TP. Plant nutrient uptake was considered an intermediate step as the phosphorus would still be released back into the river system upon decay. The hydraulic residence time of sewage discharges into the Marimba River, for a stretch of $8 \mathrm{~km}$, was calculated at $0.38 \mathrm{~d}$. This is not much to allow chemical processes leading to sufficient reductions in nitrogen levels in the river. The water and nutrient contributions of the Marimba River for the studied portion are shown in Fig. 7.

Figure 7 confirms that the major source on nutrients in Marimba River is the pond overflow which contributed $61 \% \mathrm{TN}$ and $47 \%$ TP. This was also corroborated by the observation that river nutrient levels went down considerably in October 2001 when there was no pond overflow. This overflow is a result of hydraulic overloading on the CSTW. The BNR discharges are quite within limits as little overloading is allowed in this part of the plant. BNR effluent results show that it might be possible to increase loading

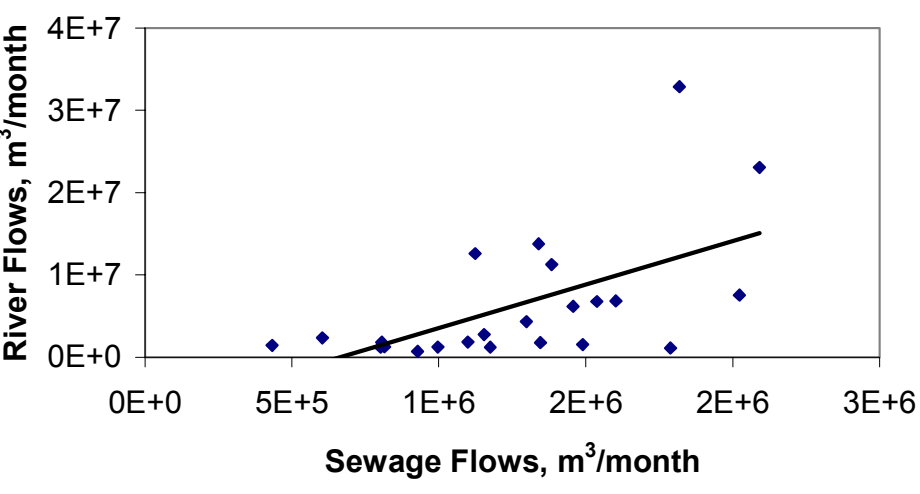

Figure 6

orrelation between average sewage effluent discharges and river flows at gauging station C24 on the Marimba River for 1999 to 2001 (Data source: City of Harare and ZINWA)

TABLE 2

Water and nutrient loads along the Marimba River

\begin{tabular}{l|c|c|c|c|c|}
\multirow{2}{*}{ Station } & \multirow{2}{*}{ Water } & \multicolumn{2}{|c|}{ TN } & \multicolumn{2}{c|}{ TP } \\
\cline { 3 - 6 } & $\mathbf{m}^{\mathbf{3} \cdot \mathbf{d}^{-1}}$ & $\mathbf{m g} \cdot \boldsymbol{\ell}^{-1}$ & $\mathbf{m g} \cdot \mathbf{d}^{-1}$ & $\mathbf{m g} \cdot \boldsymbol{\ell}^{-1}$ & $\mathbf{k g}^{-1} \mathbf{d}^{-1}$ \\
1 & 127682 & 13.5 & 1724 & 2.6 & 332 \\
2 & 127682 & 13.5 & 1724 & 2.6 & 332 \\
3 & 10656 & 24.9 & 265 & 6.2 & 66 \\
3 & 127682 & 15.6 & 1992 & 3.7 & 472 \\
5 & 117026 & 15.4 & 1802 & 4.5 & 527 \\
7 & 117026 & 18.3 & 2142 & 2.2 & 257 \\
9 & 88948 & 25.5 & 2268 & 3.1 & 276 \\
$9 U$ & 37866 & 9.6 & 364 & 1.2 & 45 \\
10 & 28078 & 26.1 & 733 & 2.6 & 73 \\
11 & 9303 & 3.5 & 33 & 0.9 & 8 \\
12 & 37866 & 7.3 & 276 & 1.2 & 45 \\
13 & 37866 & 6.2 & 235 & 1.4 & 53 \\
Seepage & 17140 & 12.0 & 206 & 7.0 & 120 \\
Runoff & 1635 & 19.7 & 32 & 11.0 & 18 \\
Pond overflow & 31182 & 44.1 & 1375 & 8.1 & 253 \\
BNR effluent & 19900 & 4.6 & 92 & 0.7 & 14 \\
& & & & & \\
\hline
\end{tabular}

TABLE 3

Summary of mass balances at important points

\begin{tabular}{|l|c|c|c|}
\hline Station & $\begin{array}{c}\text { Water, } \\
\mathbf{m}^{\mathbf{3} \cdot \mathbf{d}^{-1}}\end{array}$ & $\begin{array}{c}\mathbf{T N}, \\
\mathbf{k g} \cdot \mathbf{d}^{-1}\end{array}$ & $\begin{array}{c}\mathbf{T P}, \\
\mathbf{k g} \cdot \mathbf{d}^{-1}\end{array}$ \\
\hline 11 & 9303 & 33 & 8 \\
Seepage & 17140 & 206 & 120 \\
Runoff & 1635 & 32 & 18 \\
12 & 37866 & 276 & 45 \\
Pond overflow & 31182 & 1375 & 253 \\
BNR effluent & 19900 & 92 & 14 \\
3 & 10656 & 265 & 66 \\
C24 & 127682 & 1724 & 332 \\
Total inflow & 127682 & 2279 & 524 \\
Total outflow & 127682 & 1724 & 332 \\
Deficit: inflow - outflow & 0 & 555 & 192 \\
Deficit as \% of inflow & 0 & 24 & 37 \\
\hline
\end{tabular}




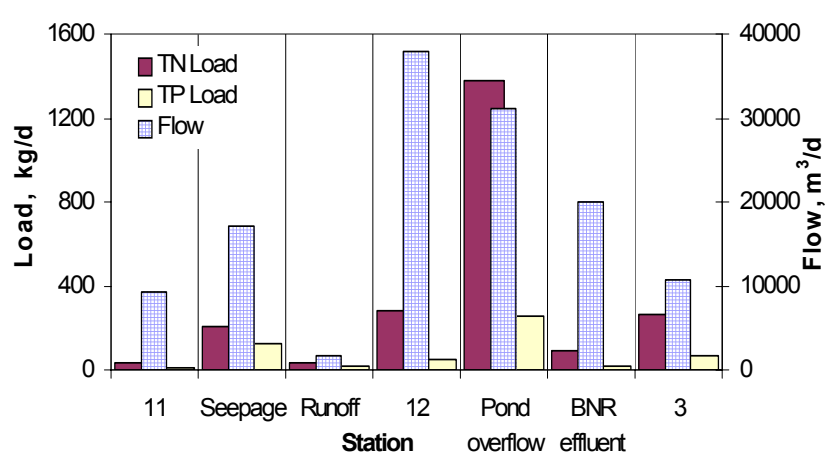

Figure 7

Water and nutrient contributions to flows at gauging station C24 on the Marimba River

to the maximum hydraulic capacity of the final clarifier without seriously compromising the quality of the effluent. Adjusting the sludge wastage rate can lower the TP value further. The results also show that the Marimba River is heavily polluted upstream of sewage discharge points. The major sources of this pollution could be sewer overflows and illegal industrial discharges. If the pond overflow is treated to BNR standard $\left(10 \mathrm{mg} \cdot \ell^{-1} \mathrm{TN}\right.$ and $1 \mathrm{mg} \cdot \ell^{-1}$ $\mathrm{TP}$ ), loads in the river could potentially be reduced by $47 \%$ for TN and $42 \%$ for TP. An improvement in the operation of pasture irrigation at Crowborough and Ingwe Farms would also greatly improve water quality in Marimba River. This would involve proper effluent/sludge distribution on the pastures, appropriate hydraulic loading of the pastures, and systematic/periodic application of the effluent/sludge mixture. Other solutions would be separate sludge disposal via landfills or incineration. Harvesting the pasture grass regularly in combination with a dedicated feedlot system for the cattle would also reduce nutrient outflows from the pastures.

\section{Pollution load reductions}

The results of the application of Eq. (2) are shown in Table 4.

In between Stations 3 and 5 there was additional seepage/ runoff discharge at Point 3 , accounting for reduced pollution attenuation. The impact of urban agriculture was expected between Points 5 and 7. The results did not show this as sewage still had a significant impact. However, pollutant reduction factors started going down after Point 5 as expected. Stretches 7 to 9 and 9 to $9 \mathrm{U}$ had highest reductions for both nitrogen and phosphorus. This was caused by removal of readily settleable and biodegradable matter in sewage effluent, principally pond overflow. These results are in contrast to Stretch 10 to 11 , which received seepage and runoff. The nitrogen and phosphorus content of seepage and runoff is not readily biodegradable. Nutrient reductions for stretches $9 \mathrm{U}$ to 12 and 12 to 13 were of different magnitudes, suggesting that there is a gradual influence of seepage/runoff especially on nitrogen loads and transformations. In the rainy season, stretch $9 \mathrm{U}$ to 12 would also be influenced by stormflow from the nearby Mufakose Township.

\section{Conclusions and recommendations}

- Nitrogen and phosphorus levels in the Marimba River show a significant influence of sewage discharges resulting in high residual nutrient levels of $13.5 \pm 2.0 \mathrm{mg} \cdot \ell^{-1}$ as $\mathrm{N}\left(1842 \mathrm{~kg} \cdot \mathrm{d}^{-1}\right)$; and $2.6 \pm 0.6 \mathrm{mg} \cdot \ell^{-1}$ as $\mathrm{P}\left(408 \mathrm{~kg} \cdot \mathrm{d}^{-1}\right)$;) on entrance into Lake Chivero.
TABLE 4

Pollution reduction with distance for different segments of the Marimba River

\begin{tabular}{|c|c|c|c|c|c|}
\hline Stretch & $\begin{array}{l}\text { Length } \\
\text { km }\end{array}$ & $\begin{array}{c}\text { TN } \\
\partial \text { Load, } \\
\mathrm{kg}^{-1} \cdot \mathrm{d}^{-1}\end{array}$ & $\begin{array}{c}\text { TP } \\
\text { Reduc- } \\
\text { tion } \\
\text { factor, } \\
\mathbf{g} \cdot \mathbf{s}^{-1} \cdot \mathbf{m}^{-1}\end{array}$ & $\begin{array}{c}\partial \text { Load, } \\
\mathbf{k g} \cdot \mathbf{d}^{-1}\end{array}$ & $\begin{array}{l}\text { Reduc- } \\
\text { tion } \\
\text { factor, } \\
\mathbf{g} \cdot \mathbf{s}^{-1} \cdot \mathbf{m}^{-1}\end{array}$ \\
\hline $1-2$ & 3.5 & 0 & 0.0000 & 0 & 0.00000 \\
\hline $2-3$ & 2.9 & 268 & 0.0011 & 140 & 0.00056 \\
\hline 3'-5 & 3.2 & 76 & 0.0003 & 120 & 0.00043 \\
\hline $5-7$ & 0.7 & 339 & 0.0056 & -269 & -0.00445 \\
\hline $7-9$ & 0.6 & 859 & 0.0166 & 91 & 0.00176 \\
\hline 9-9U & 0.5 & -438 & -0.0101 & 36 & 0.00084 \\
\hline 9U-12 & 2.0 & -87 & -0.0005 & 0 & 0.00000 \\
\hline $12-13$ & 2.1 & -42 & -0.0002 & 8 & 0.00004 \\
\hline $10-11$ & 4.1 & -700 & -0.0020 & -65 & -0.00018 \\
\hline
\end{tabular}

NB. A minus sign (-) denotes an increase in nutrient levels for that stretch due to point or non-point sources

- The flow pattern at Station 2 (gauging Station C24) showed a weak correlation (correlation coefficient $=0.49$ ) between sewage discharges and river runoff. This suggests other significant sources of incidental discharges upstream, e.g. industrial discharges, sewer overflows, etc.

- Pond overflow is the major source of nutrients in the Marimba River. If this were treated to BNR standards, nutrient loads in the Marimba River would reduce by about $47 \%$ for $\mathrm{TN}$ and $42 \%$ for TP

From this study it is recommended that CSTW be urgently upgraded and that the pasture irrigation system be optimised for nutrient reduction. The City of Harare should also substantially reduce pollution upstream of sewage discharge. This involves stricter control and enforcement of industrial and commercial polluting activities, encouraging reuse and recycling, localised treatment of sewage, and control of urban agriculture.

\section{Acknowledgements}

The authors gratefully acknowledge assistance from SIDA through the Water Research Fund for Southern Africa (WARFSA), the Netherlands Government through the WREM Project, City of Harare, and the Zimbabwean National Water Authority (ZINWA).

\section{References}

BILLINGS WD, GOLLEY F, LANGE OL, OLSON JS and REMMERT H (1984) Ecological Studies, Analysis and Synthesis. Springer-Verlag Inc., New York.

DEPARTMENT OF WATER (1995) Assessment of Surface Water Resources in the Manyame Catchment - Zimbabwe; Streamflow Gauging and Conceptual Hydrological Modelling. SMHI Hydrology No. 60, Department of Water Development, Government of Zimbabwe, Harare.

FATOKI OS, MUYIMA NYO and LUJIMA N (2001) Situation Analysis of Water Quality in the Umtata River Catchment. Water SA 27 (4) 467-473.

HLAVINEK P and RIHA J (2001) Stream Water Quality Model as a Tool for the Assessment of Impact of Pollution Sources Improvements in the 
River Basin. Proc. IWA Conference on Water and Wastewater for Developing Countries. Kuala Lumpur, Malaysia, 29-31 October 2001, 116-123.

JICA REPORT (1996) The Study of Water Pollution Control in Upper Manyame River Basin in the Republic of Zimbabwe. MLGRUD, Nippon Jogeduido Sekkei Co. Ltd., Nippon Koei Co. Ltd, September 1996.

LEWIS WM, SAUNDERS JF, CRUMPACKER DW and BRENDECKE C (1984) Eutrophication and Land Use, Springer-Verlag New York Inc, New York, USA.

KAMUDYARIWA C (2000) Seasonal Variation of Water Quality with Respect to Anthropogenic Activities along Mukuvisi River, Harare, Zimbabwe. M.Sc. Thesis, IHE Delft, the Netherlands.

MACHENA C (1997) The pollution and self-purification capacity of the Mukuvisi River. In: Moyo NAG (ed.) Lake Chivero: A Polluted Lake. University of Zimbabwe Publications, Harare, Zimbabwe. 75-91.

MANJONJO M (1999) Impact of Sewage and Sludge Effluent on Surface Water, A Case Study of the Impact of Crowborough Farm on Marimba River in Harare, Zimbabwe. M.Sc. WREM Thesis, University of Zimbabwe, Zimbabwe.

MATHUTHU AS, MWANGA K and SIMORO A (1997) Impact assessment of industrial and sewage effluents on water quality of the receiving Marimba River in Harare. In Moyo NAG (ed.) Lake Chivero: A Polluted Lake. University of Zimbabwe Publications, Harare, Zimbabwe. 43-52.

MAWERE M (2001) Land Application of Sewage, The Role of Crowborough Pasture Irrigation in the Reduction of Nutrient Loads to Marimba River. M.Sc. Thesis, IHE Delft, the Netherlands.

McKENDRICK J (1982) Water Supply and Sewage Treatment in Relation to Water Quality in Lake Mcllwaine. In: Thornton JA \& Nduku WK (eds.) Lake Mcllwaine; The Eutrophication and Recovery of a Tropical African Man-Made Lake, Dr W Junk Publishers, The Hague, the Netherlands. 202-217.

MOYO NAG (ed.) (1997) Lake Chivero: A Polluted Lake. University of Zimbabwe Publications, Harare, Zimbabwe.

MOYO NAG and WORSTER K (1997) The Effects of Organic Pollution on the Mukuvisi River, Harare, Zimbabwe. In Moyo, NAG (ed.) Lake Chivero: A Polluted Lake, University of Zimbabwe Publications, Harare, Zimbabwe. 53-63.

NHAPI I, SIEBEL M and GIJZEN HJ (2001) Dry Season Inflow and Export of Nutrients from Lake Chivero. Proc. Zimbabwe Inst. Eng. 2 (1) 3341.

STANDARD METHODS (1995) Standard Methods for the Examination of Water and Wastewater (19th edn.), American Public Health Association/American Water Works Association/Water Environment Federation, Washington DC, USA.

THORNTON JA (1982) Research perspectives. In: Thornton JA and Nduku WK (eds.) Lake Mcllwaine - The Eutrophication and Recovery of a Tropical Man-made Lake. Dr. W. Junk Publishers, The Hague, the Netherlands. 227-231.

THORNTON JA and NDUKU WK (1981) Nutrients in runoff from small catchments with varying land usage in Zimbabwe. Trans. Zimbabwe Sci. Assoc. 61 (2) 14-26.

WELCH EB and LINDELL T (1980) Ecological Effects of Waste Water. Cambridge University Press, London, UK

WHO (1984) Guidelines for Drinking Water Quality. World Health Organisation, Geneva.

ZARANYIKA MF (1997) Sources and levels of pollution along Mukuvisi River: A review. In: Moyo NAG (ed.) Lake Chivero: A Polluted Lake. University of Zimbabwe Publications, Harare, Zimbabwe. 35-42. 
